\title{
Seed germination performances of Styrax species help understand their distribution in Cerrado areas in Brazil
}

\author{
Camila Kissmann; Gustavo Habermann $\left({ }^{*}\right)$ \\ Univ Estadual Paulista (UNESP), Instituto de Biociências, Departamento de Botânica, Av. 24-A, 1515, 13506-900 \\ Rio Claro (SP), Brazil. \\ (*) Corresponding author: ghaber@rc.unesp.br
}

Received: July 15, 2013; Accepted: July 26, 2013

\begin{abstract}
In this descriptive paper, we described germination responses of Styrax pohlii, S. camporum and S. ferrugineus seeds at $5,10,15,20,25,30,35,40$ and $45^{\circ} \mathrm{C}$. We also assessed the percentage germination (\%G) of S. pohlii seeds with different seed water contents because, as a forest species, it seems to have recalcitrant seed behavior. Intrigued by the capacity of seeds of this species to germinate directly from puddles formed on poorly drained soils of riparian forests, where it typically occurs, we also tested the effect of de-pulping fruits on germination of S. pohlii seeds under hypoxia and normoxia conditions. In addition, we checked whether distinct concentrations of gibberellic acid $\left(\mathrm{GA}_{3}\right)$ could break S. ferrugineus seed dormancy, a typical seed behavior of Cerrado species. No germination occurred at 5,40 and $45^{\circ} \mathrm{C}$, regardless of the species. The optimal temperature for germination was $20^{\circ} \mathrm{C}$ for S. pohlii and $25^{\circ} \mathrm{C}$ for S. camporum. However, S. ferrugineus seeds showed a very low \%G, regardless of the temperature, and $\mathrm{GA}_{3}$ could not consistently break possible physiological seed dormancy. For $\mathrm{S}$. pohlii seeds, the higher the seed desiccation the lower the \%G, and fruit pulp removal showed to be essential for seed germination. S. pohlii seeds germinated independently of oxygenation conditions.
\end{abstract}

Key words: hypoxia, Styrax pohlii, S. camporum, S. ferrugineus, temperature, desiccation seed tolerance.

\section{Desempenho germinativo de sementes de espécies de Styrax ajuda a entender sua distribuição em áreas de Cerrado no Brasil}

\section{Resumo}

Neste trabalho descritivo foi mostrada a resposta germinativa das sementes de Styrax pohlii, S. camporum e S. ferrugineus a $5,10,15,20,25,30,35,40$ e $45^{\circ} \mathrm{C}$. Avaliou-se também a porcentagem de germinação (\%G) de sementes de S. pohlii com diferentes conteúdos de água, pois, por ser uma espécie florestal, suas sementes parecem ser recalcitrantes. Dada a capacidade de as sementes dessa espécie germinarem diretamente em poças d'água formadas em solos mal drenados nas florestas ripárias, onde a espécie tipicamente ocorre, também testou-se o efeito do despolpamento dos frutos para a germinação de sementes de S. pohlii em condições de hipóxia e normóxia. Além disso, verificou-se se diferentes concentrações de ácido giberélico (GA A $)$ poderiam quebrar a dormência das sementes de S. ferrugineus, que é característica de sementes de espécies do Cerrado. Não houve germinação a 5,40 e $45^{\circ} \mathrm{C}$, independente da espécie. A temperatura ótima para a germinação foi $20^{\circ} \mathrm{C}$ para $\mathrm{S}$. pohlii e $25^{\circ} \mathrm{C}$ para S. camporum. Porém, as sementes de S. ferrugineus mostraram \%G muito baixa, independente da temperatura, e o GA $\mathrm{G}_{3}$ ão quebrou consistentemente a possível dormência fisiológica dessas sementes. Para as sementes de S. pohlii, quanto maior a dessecação, menor \%G, e a remoção da polpa dos frutos mostrou ser essencial para a germinação das sementes. As sementes de S. pohlii germinaram independentemente das condições de oxigenação.

Palavras-chave: hipóxia, Styrax pohlii, S. camporum, S. ferrugineus, temperatura, tolerância à dessecação.

\section{INTRODUCTION}

Seed germination performances studied under laboratory conditions are critical for the understanding of species distribution in nature. Many germination results obtained under laboratory conditions have been reported (ZAIDAN and CARreira, 2008) for species of the Brazilian savanna (Cerrado), which is a biodiversity hot spot in South America
(KuInK and Machado, 2005). However, few results, if any, possess relationships with data obtained in the field. On the other hand, the plant reproductive success and species distribution are intimately related because of the ability of seeds to germinate and establish plants in natural communities (Kissmann et al., 2012).

Seed germination is widely influenced by environmental resources, such as sunlight (TAKAKI, 2001), temperature 
(Fenner, 1991) and water availability (Fenner and Thompson, 2005). Nevertheless, seed dormancy, maturity, tolerance to desiccation and age are intrinsically important (Bewley and BlaCK, 1994; Daws et al., 2004). Requirements for germination are species-specific, but these requirements may also vary between and within populations from which seeds are selected for laboratory studies (GUTTERMAN, 2000).

Unlike orthodox seeds of most Cerrado woody species, recalcitrant seeds or desiccation-intolerant seeds are dispersed with high water content and active metabolism (RoBERTS, 1973). These species usually occur in humid environments, being palm trees typical examples (RoвERTo et al., 2011), but some species showing seeds with recalcitrant behavior also occur in dry environments (PAMMENTER and BerJaK, 2000). Therefore, no desiccation during maturation enables recalcitrant seeds to rapidly germinate after dispersion, because these seeds do not require rehydration (BEWLEY and BLACK, 1994). This is an advantage in humid environments because these seeds are able to promptly use natural resources available. On the other hand, rapid germination may not be considered advantageous in unpredictable habitats, such as the savannas. Seeds of savanna species commonly exhibit dormancy, preventing these seeds from germinating under unfavorable conditions (ZAIDAN and CARreira, 2008).

Styrax L. includes species with distinct distribution in the Cerrado. S. pohlii A. DC. is a forest species, frequently occurring in riparian forests within Cerrado areas (TeIXeIrA and Assis, 2005). S. camporum Pohl. is widely distributed in the Cerrado, and it is greatly favored by conditions at the edge of forest fragments (HaBERMANn et al., 2011), whereas S. ferrugineus Nees \& Mart. is well adapted to savanna-type physiognomies that exist in the Cerrado (Habermann et al., 2011). Seed germination performances of $S$. camporum, which disperses its seeds during the dry season (April - August), was studied in the field and this study indicated that its thick tegument reflects its capacity to endure long and severe dry seasons of the Cerrado areas (Kissmann et al., 2012). However, it is unclear whether $S$. pohlii seeds are tolerant to desiccation and how it germinates if fruits are not de-pulped (by animals) or if fruits and seeds fall into puddles on poorly drained soils of riparian forests. In addition, low percentage germination of $S$. ferrugineus seeds (BARBOSA et al., 1985) is related to some unknown dormancy.

This is a descriptive paper, in which we characterized germination responses of seeds of these three species under a range of temperatures, under laboratory conditions. We assessed the germination performances of $S$. poblii seeds with different water contents, and when submitted to hypoxia and normoxia, and also the effect(s) of de-pulping $S$. pohlii fruits on seed germination. Finally, we used different concentrations of gibberellic acid $\left(\mathrm{GA}_{3}\right)$ to break possible physiological seed dormancy in $S$. ferrugineus. We discuss the distribution of these species based on data obtained through field experiments (Kissmann et al., 2012) and under laboratory conditions.

\section{MATERIAL AND METHODS}

\section{Plant material}

Mature fruits of $S$. ferrugineus were harvested from October to December 2011 in a fragment (470 ha; $22^{\circ} 18^{\prime} \mathrm{S}$ and $47^{\circ} 11^{\prime} \mathrm{W}$ ) of Cerrado sensu stricto (s. str.), which is a savanna-type physiognomy of the Cerrado sensu lato (s. l.). Fruits of $S$. camporum were harvested from April to May 2011 in a remnant ( $37 \mathrm{ha} ; 22^{\circ} 15^{\prime} \mathrm{S}$ and $47^{\circ} 00^{\prime} \mathrm{W}$ ) of a forest physiognomy called 'Cerradão' (augmentative of Cerrado, in Portuguese), and fruits of $S$. pohlii were collected from February to March 2011 in a riparian forest fragment (32 ha; $24^{\circ} 00^{\prime} S$ and $75^{\circ} 30^{\prime} \mathrm{W}$ ). All these sites are located in São Paulo state, Brazil. As described, these harvests were performed after the respective dispersal time of each of the three species, and the seeds of none of the three species were stored prior to germination tests.

After harvesting, the fruits were de-pulped through friction against a $1 \mathrm{~mm}$-steel sieve, under tap water, aiming to mimic natural conditions of seed dispersal, either by considering seeds after digestion or as regurgitated seeds (Kissmann et al., 2012). Part of the sample of $S$. pohlii fruits was not de-pulped in order to test the effect of pulp on seed germination. The seed water content of samples of each of the three species was gravimetrically determined (adapted from Ista, 2011) soon after the harvests.

\section{Temperature experiments}

De-pulped seeds of the three species were immersed in a solution of sodium hypochlorite $(1 \%, \mathrm{v} / \mathrm{v})$ for $1 \mathrm{~min}$ to prevent fungal infection during germination. Disinfected seeds were placed on filter paper that was wetted with distilled water within transparent plastic boxes called "gerboxes" $(13 \times 13 \times 4 \mathrm{~cm})$. Thirty seeds per gerbox (replications) were incubated under constant fluorescent light $\left(80 \mu \mathrm{mol} \mathrm{m}^{-2} \mathrm{~s}^{-1}\right)$ within germination chambers (Eletrolab, São Paulo, Brazil), in which constant temperatures were set to $5,10,15,20$, $25,30,35,40$ and $45^{\circ} \mathrm{C}$.

At the end of the tests, non-germinated seeds were submitted to the tetrazolium test to assess their viability. For this test, seed halves were placed in a tetrazolium solution $(0.5 \%, v / v)$ at $\mathrm{pH} 6.5-7.0$, and incubated at $35^{\circ} \mathrm{C}$ in the dark for four hours (adapted from IsTA, 2011). These seeds were classified into viable or unviable seeds, according to the degree of staining of embryos.

For each of the three species, it was used a completely randomized experimental design, with six replications. The 
number of germinated seeds was monitored every other day until 90 days after sowing (DAS) for $S$. camporum and S. ferrugineus, and until 60 DAS for $S$. pohlii. We did not monitor seeds under green light because seeds of these three species are aphotoblastic, being such behavior confirmed for S. camporum seeds (Simâo et al., 2013). Protrusion of roots with $2 \mathrm{~mm}$ in length was used as evidence of germination. The percentage of germinated seeds $(\% \mathrm{G})$; the relative frequency of germination $(\mathrm{RF}=\mathrm{ni} / \mathrm{Nt}$, where $\mathrm{ni}$ is the number of germinated seeds between times ti-1 and $\mathrm{ti}$, and $\mathrm{Nt}$ is the total number of germinated seeds); and the mean germination time $[\mathrm{T}=(\Sigma(\mathrm{ni} \mathrm{ti}) / \Sigma$ ni $)$, where $\mathrm{ni}$ is the number of germinated seeds in the time interval from ti-1 to ti] were calculated according to LABOURIAU and Agudo (1987).

For S. pohlii and S. camporum seeds, a one-way analysis of variance (ANOVA) was performed to evaluate differences in $\% \mathrm{G}$ between $10,15,20,25,30$ and $35^{\circ} \mathrm{C}$, whereas for $S$. ferrugineus the same procedure was used to check differences in \%G between $10,15,20$ and $25^{\circ} \mathrm{C}$ because not all species showed germinated seeds under the nine temperatures tested. Mean values were compared by Tukey's test $(\mathrm{p}=0.05)$, after transforming $\% \mathrm{G}$ into $\arcsin (\% \mathrm{G} / 100)^{0.5}$.

\section{Germination tests of S. pohlii seeds with different seed water contents}

De-pulped seeds of $S$. pohlii were dried inside a glass desiccator containing silica gel (anhydrous calcium chloride), which was replaced whenever its color started changing from blue to purple. The target seed water content was obtained by monitoring the loss of fresh mass in seed samples. The final sample dry mass was calculated according to the following equation: $M f=M_{0}\left[\left(100-C_{0}\right) /\left(100-C_{f}\right)\right]$. In this equation, $\mathrm{Mf}$ represents the final target seed mass $(\mathrm{g})$, $\mathrm{C}_{0}$ and $\mathrm{C}_{\mathrm{f}}$ are the initial and final (target) water contents (\%), respectively, while $M_{0}$ is the initial sample seed mass (Cromarty et al., 1990).

Seed water content was gravimetrically determined before and after drying samples for target values (adapted from IsTA, 2011). Water content of non-dried seeds (control seeds) was $50 \pm 0.5 \%$. After drying samples, water contents of the three seed samples were $43 \pm 0.1,33 \pm 1.1$, and $12 \pm 0.4 \%$.

Seed samples (180 seeds) of each of the four treatments (the three seed water contents, and the control) underwent disinfestation procedures and germination tests as previously described. Six gerboxes containing 30 seeds each from each of the four treatments were put under constant fluorescent light $\left(80 \mu \mathrm{mol} \mathrm{m}^{-2} \mathrm{~s}^{-1}\right)$ within germination chambers (Eletrolab, Brazil), under constant $25^{\circ} \mathrm{C}$.

A one-way ANOVA was used to test differences in \%G between seed samples of each of the four treatments. Mean results were also compared by the Tukey's test (performed at the $5 \%$ significance level).

\section{Germination tests of S. pohlii non de-pulped fruits and hypoxia effects on germination}

De-pulped (seeds) and non de-pulped fruits of $S$. pohlii were placed to germinate within gerboxes, under normoxia and hypoxia conditions. Normoxia conditions was obtained by placing the seeds on wet filter paper within gerboxes, and hypoxia conditions was obtained by placing seeds on filter paper, and adding distilled water so that $2 / 3$ of each seed was covered.

Water used for hypoxia conditions was stored in containers prior to the study. The water level in gerboxes was checked every other day, and whenever necessary water was supplemented, in a slow and gentle manner, in order to avoid bubbles and/or increase in dissolved oxygen (DO) concentration. DO concentration in gerboxes was assessed by the iodometric method (Golterman et al., 1978), and it stayed at $4.5 \pm 0.2 \mathrm{mg} \mathrm{L}^{-1}$ throughout the study, which is much lower than $\mathrm{DO}$ values found in floodplains of the Amazonian Forest (Bracho-Nunez et al., 2012; Furch and Junk, 1997). This procedure aimed to mimic DO concentration into puddles on the floor of swamp forests, where $S$. pohlii seeds and seedlings are found.

De-pulping, disinfection and germination procedures were conducted as already described. The gerboxes were placed under constant fluorescent light $\left(80 \mu \mathrm{mol} \mathrm{m}^{-2} \mathrm{~s}^{-1}\right)$ within germination chambers (Eletrolab, Brazil), in which the temperature was set to constant $25^{\circ} \mathrm{C}$. Data were used to calculate the cumulative percentage germination and mean germination time (T), according to Labouriau and Agudo (1987).

A two-way ANOVA was carried out to test the effects of the two-level 'pulp' and 'oxygenation' factors, as well as their interactions on $\% \mathrm{G}$ and mean germination time $(\mathrm{T})$. The Tukey's test was performed for post hoc comparisons of mean results at the 5\% significance level.

\section{Germination tests of $\mathbf{G A}_{3}$-treated seeds of S. ferrugineus}

Seed samples of $S$. ferrugineus were immersed in 0, 50, 100, 150, 300 and $600 \mathrm{mg} \mathrm{L}^{-1} \mathrm{GA}_{3}$ (gibberellic acid, Gibco BRL, Grand Island, NY, USA) oxygenated solutions for $24 \mathrm{~h}$, since this interval is satisfactory for the initial imbibition of $S$. ferrugineus seeds (KIssmann et al., 2012). After this procedure, these seeds were submitted to germination tests as previously described. Gerboxes were placed under constant fluorescent light $\left(80 \mu \mathrm{mol} \mathrm{m}^{-2} \mathrm{~s}^{-1}\right)$ within a germination chamber (Eletrolab, Brazil), in which the temperature was set to constant $25^{\circ} \mathrm{C}$.

A one-way ANOVA was conducted to detect significant differences in \%G between seed samples treated with the six different $\mathrm{GA}_{3}$ solutions. The Tukey's test was once 
more performed at the $5 \%$ significance level to compare mean results.

\section{RESULTS}

The initial seed water content (after dispersion) was $50 \pm 0.5 \%$, $11 \pm 0.01 \%$ and $18.8 \pm 0.42 \%$ for S. pohlii, S. camporum and $S$. ferrugineus seeds, respectively.

Seeds of the three species started germinating at $10^{\circ} \mathrm{C}$ and no germination was observed when seeds were placed to germinate at 5,40 or $45^{\circ} \mathrm{C}$. Besides not germinating under these temperatures, $S$. ferrugineus seeds did not germinate at 30 and $35^{\circ} \mathrm{C}$.
S. pohlii seeds exhibited the same $\% \mathrm{G}$ when exposed to $10,15,20,25$ and $30^{\circ} \mathrm{C}$, but at $35^{\circ} \mathrm{C}$ seeds of this species showed lower $\% \mathrm{G}$ as compared to the other temperatures (Figure 1a). In addition, the mean germination time (T) was the lowest at $20^{\circ} \mathrm{C}$ for S. pohlii seeds (Figure $1 \mathrm{~b}$ ). $S$. camporum seeds showed great variation in $\% \mathrm{G}$ assessed at different temperatures, however, this species showed the best germination performance at $25^{\circ} \mathrm{C}$, although this result did not differ from $\% \mathrm{G}$ measured at 20,30 and $35^{\circ} \mathrm{C}$ (Figure 1c). In addition, $S$. camporum seeds seemed to best distribute germination over time at $25^{\circ} \mathrm{C}$ (Figure 2b,e,h,k,n,q). Most seeds of $S$. pohlii and $S$. camporum that did not germinate at temperatures ranging from 10 to $35^{\circ} \mathrm{C}$ were not viable after 60 and 90 days, respectively, as evidenced by the tetrazolium test.

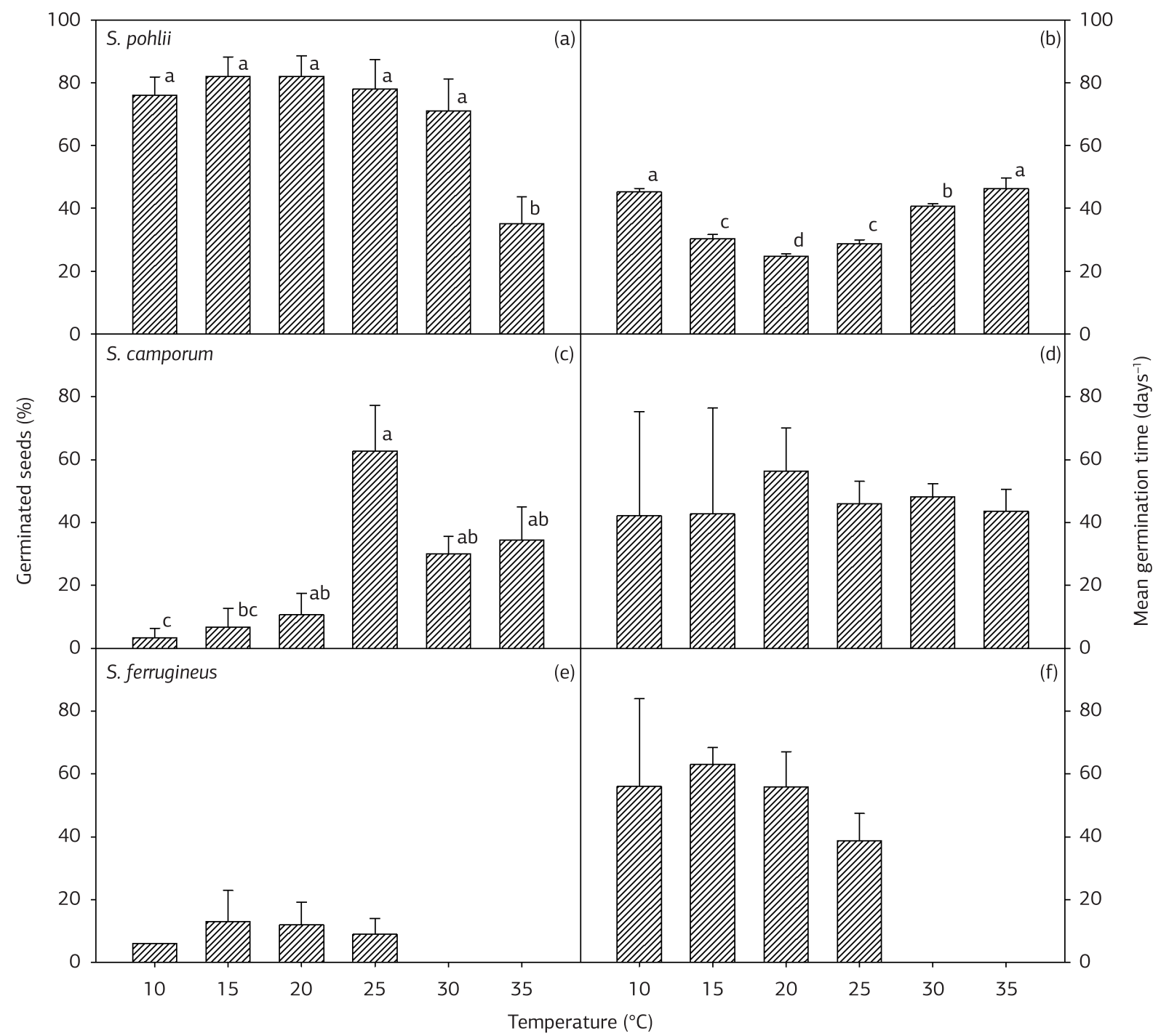

Figure 1. Percentage germination (a, c, e) and mean germination time (b, d, f) of S. pohlii and S. camporum seeds at 10, 15, 20, 25, 30 and $35^{\circ} \mathrm{C}$, and $S$. ferrugineus seeds at $10,15,20$ and $25^{\circ} \mathrm{C}$, under fluorescent light $\left(80 \mu \mathrm{mol} \mathrm{m} \mathrm{s}^{-1}\right)$. Columns represent mean values $(\mathrm{n}=6)$ and vertical bars are S.D. Different letters show significant differences $(\mathrm{p}=0.05)$ between treatments, and the absence of letters indicates a lack of significant differences between treatments. 


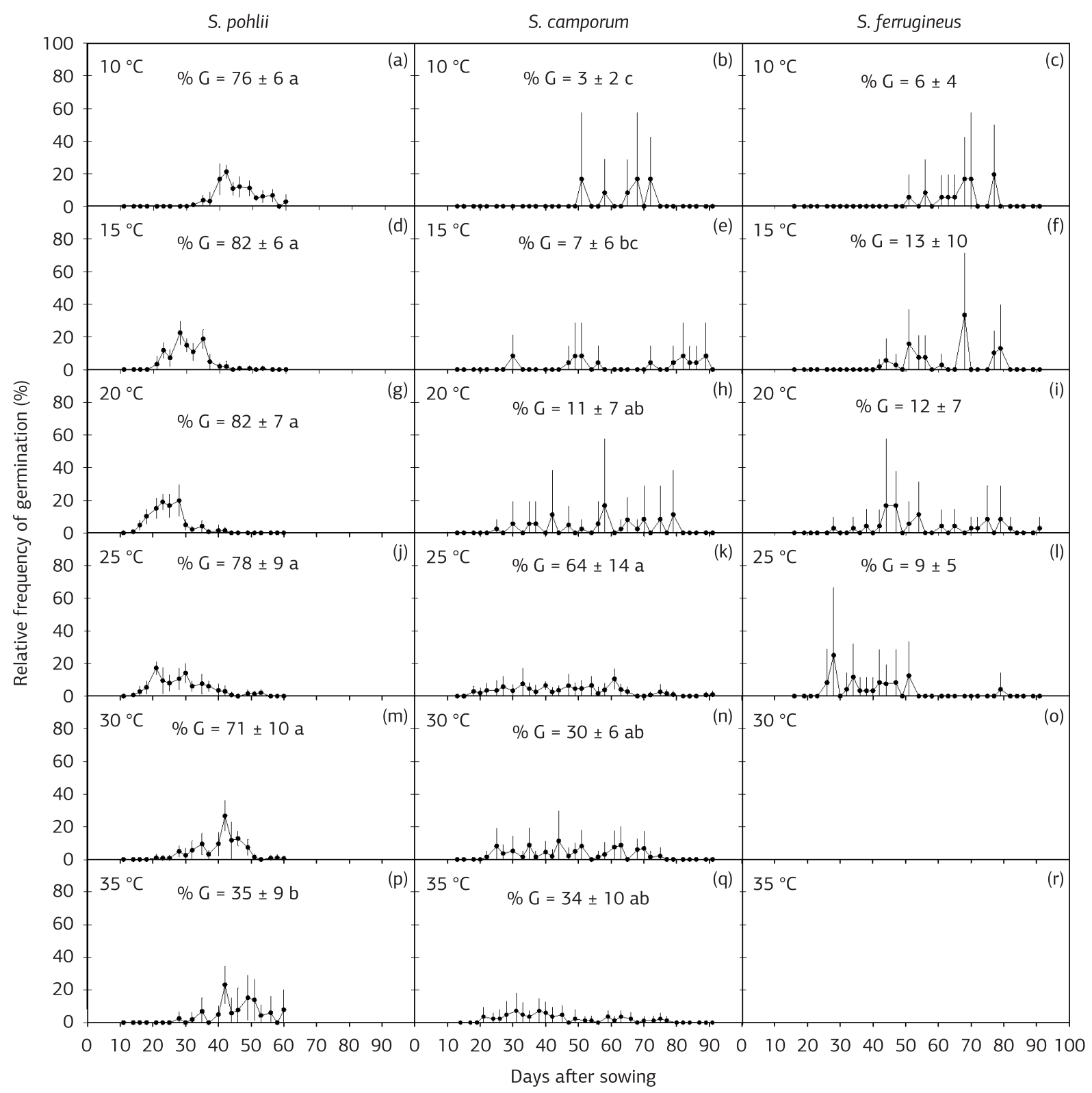

Figure 2. Relative frequency of germination of $S$. pohlii and S. camporum seeds at $10,15,20,25,30$ and $35^{\circ} \mathrm{C}$, and $S$. ferrugineus seeds at 10 , 15,20 and $25^{\circ} \mathrm{C}$, under fluorescent light $\left(80 \mu \mathrm{mol} \mathrm{m}^{-2} \mathrm{~s}^{-1}\right)$. Dots represent mean values $(\mathrm{n}=6)$, and vertical bars are S.D. $\% \mathrm{G}=$ percentage germination \pm S.D.; Different letters show significant differences $(p=0.05)$ in $\% G$ between temperatures tested for each species.

S. ferrugineus seeds showed conspicuously low \%G (Figure 1e) and similar T at 10, 15, 20 and $25^{\circ} \mathrm{C}$ (Figure 1f). Compared to seeds of S. pohlii (best $\% \mathrm{G}=82 \pm 6.5 \%$ at $20^{\circ} \mathrm{C}$; Figure 1a,b) and S. camporum (best $\% \mathrm{G}=64 \pm 14$ at $25^{\circ} \mathrm{C}$; Figure 1c,d), S. ferrugineus seeds, in general, exhibited less than half of $\% \mathrm{G}$ values of the other two species, and after 90 days, $50 \%$ of these seeds remained viable.

Seed germination of the three species was well distributed over time and no synchronization/concentration of this response was observed, even at temperatures that returned the highest \%G (Figure 2). At such temperatures, S. pohlii seeds started germinating within 14 days (Figure $2 \mathrm{~g}$ ), while
S. camporum and S. ferrrugineus seeds started germinating within 20-25 days (Figure 2k,f).

The seed water content negatively affected \%G of S. pohlii seeds. The higher the seed desiccation the lower the $\% \mathrm{G}$, but seed samples with $12 \%$ water content were still able to germinate (Figure 3). Seeds with $43 \%$ and $32 \%$ water content exhibited germination peaks earlier than seeds with $50 \%$ water content (Figure 3).

S. pohlii non de-pulped seeds showed great fungal infection, which led to $100 \%$ mortality. On the other hand, the pulp removal resulted in $83 \%$ germination, regardless of oxygenation conditions (Figure 4). Interestingly, seeds of this 


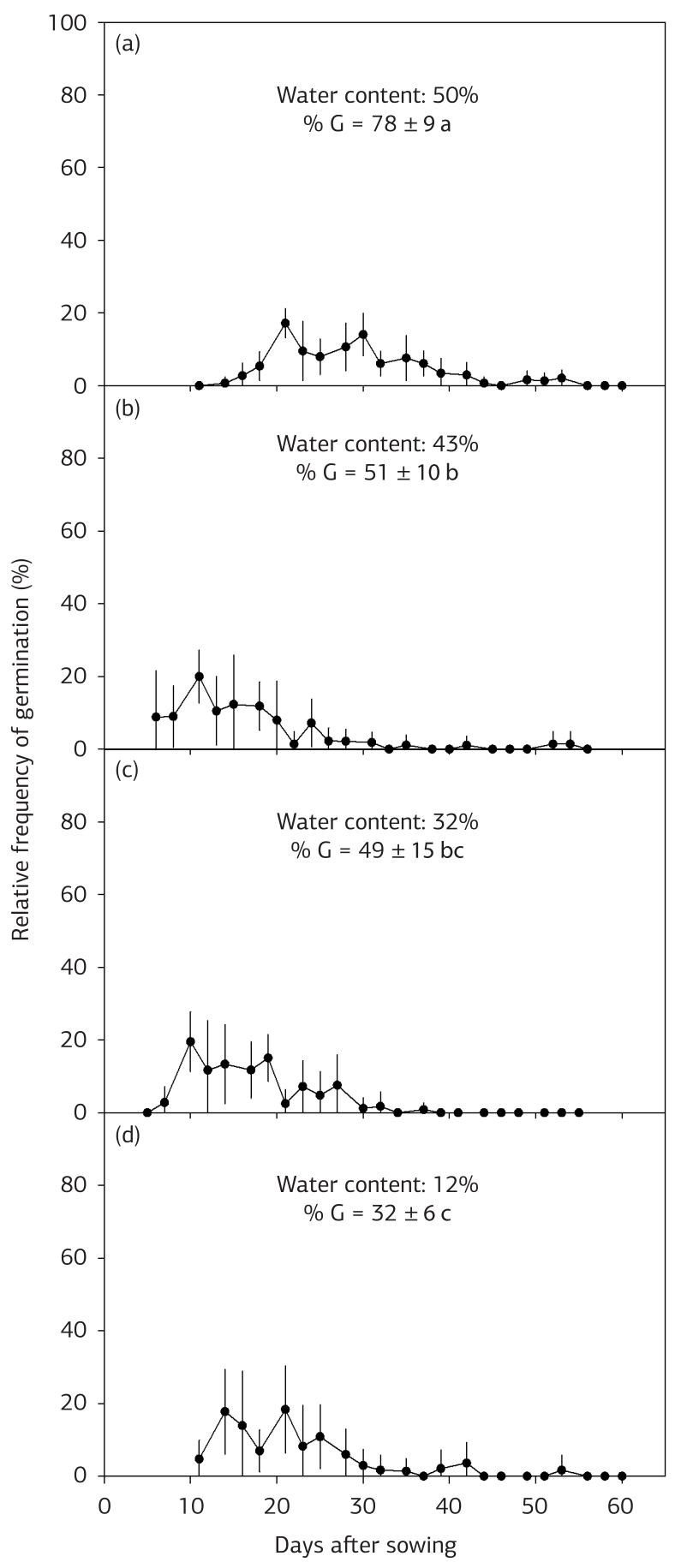

Figura 3. Relative frequency of germination of $S$. pohlii seeds, at $25^{\circ} \mathrm{C}$ and under fluorescent light $\left(80 \mu \mathrm{mol} \mathrm{m} \mathrm{m}^{-2} \mathrm{~s}^{-1}\right)$, in response to seed water contents of $50 \%, 43 \%, 32 \%$ and $12 \%$. Dots represent mean values $(\mathrm{n}=6)$ and vertical bars are S.D. $\% \mathrm{G}=$ percentage germination \pm S.D.; Different letters show significant differences $(\mathrm{p}=0.05)$ in $\% \mathrm{G}$ between treatments.

species were able to germinate even when partially covered by a water layer (hypoxia), showing the same germination performance as compared to normoxia conditions (Figure 4).

S. ferrugineus seeds treated with $100 \mathrm{mg} \mathrm{L}^{-1} \mathrm{GA}_{3}$ showed $17 \pm 11 \%$ germination, which was $6 \%$ higher than the result

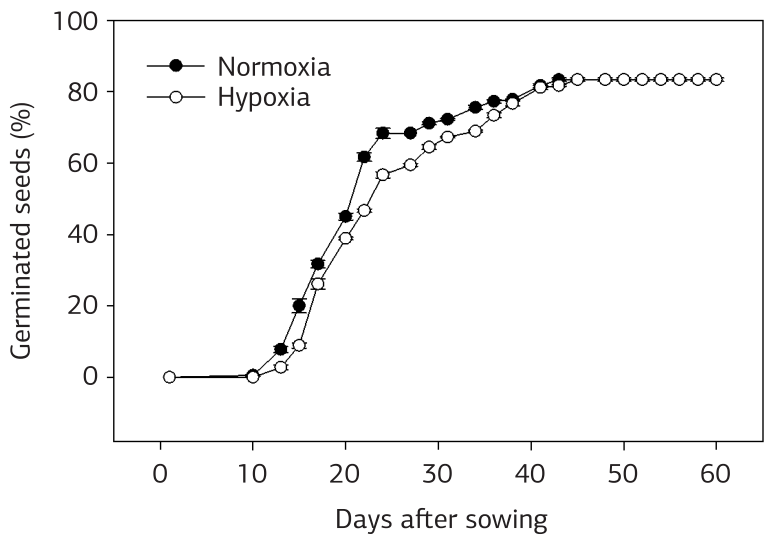

Figure 4. Cumulative percentage germination of $S$. pohlii seeds, at $25^{\circ} \mathrm{C}$ and under fluorescent light $\left(80 \mu \mathrm{mol} \mathrm{m} \mathrm{m}^{-2}\right)$, submitted to normoxia and hypoxia conditions. Dots represent mean values $(n=6)$ and vertical bars are S.D.

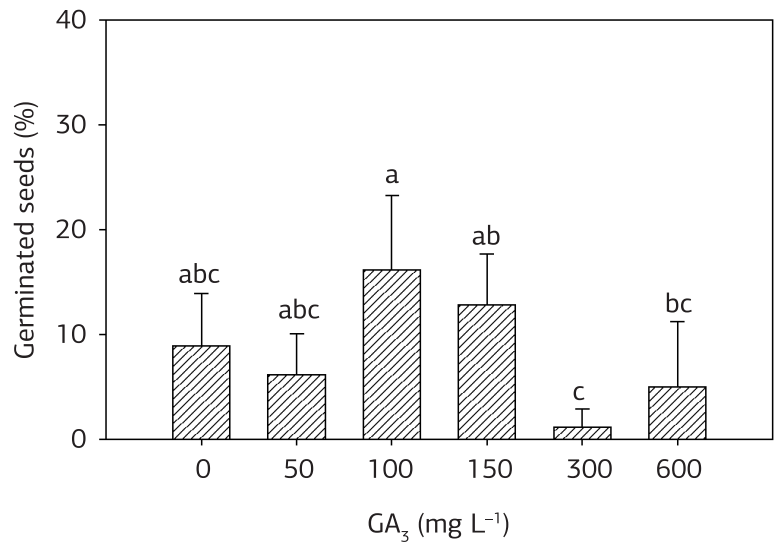

Figure 5. Percentage germination of $S$. ferrugineus seeds, at $25^{\circ} \mathrm{C}$ and under fluorescent light $\left(80 \mu \mathrm{mol} \mathrm{m}^{-2} \mathrm{~s}^{-1}\right)$ in response to $\mathrm{GA}_{3}$ treatments. Columns represent mean values $(n=6)$ and vertical bars are S.D. Distinct letters show significant differences $(\mathrm{p}=0.05)$ between treatments.

exhibited by control seeds ( $\% \mathrm{G}=9 \pm 5 \%)$. On the other hand, besides being extremely variable, $\mathrm{GA}_{3}$ did not consistently improve $\% \mathrm{G}$ (Figure 5).

\section{DISCUSSION}

Limiting temperatures for seed germination, or 'cardinal temperatures', define in a species-specific manner the range of temperature at which germination is possible, allowing inferences about the origin of species (Labouriau, 1983). Seeds of $S$. pohlii and S. camporum, which are typical of forest physiognomies of the Cerrado, germinate in a wide range of temperatures (Figure 1a,c) in relation to seeds of $S$. ferrugineus (Figure 1e), which is a typical savanna species. Considering the optimal temperature for germination as the one that promotes the highest $\% \mathrm{G}$ within the lowest mean 
germination time (BEWLEY and BLACK, 1994), our results showed that the optimal temperature for $S$. pohlii was $20^{\circ} \mathrm{C}$ (Figure 1a,b), and for S. camporum, it was $25^{\circ} \mathrm{C}$ (Figure 1c,d). The ability of these seeds to germinate within a wide range of temperatures may represent a competitive advantage in Cerrado areas. In fact, seeds of these three species buried in different physiognomies of the Cerrado areas showed prompt germination after 60 days (KIssmann et al., 2012). However, the germination performance of $S$. ferrugineus seeds is particularly intriguing. Under field conditions (Kissmann et al., 2012), $40 \%$ of seeds of each of the three species had germinated after 60 days, but in the present study S. ferrugineus seeds showed $10 \%$ germination, regardless of temperature (Figure 1e). We did not test alternate temperatures (e.g. diurnal/nocturnal), but all these observations suggest possible effects of thermal amplitude occurring in soil seed banks, which could break any seed dormancy, as generally suggested by Zaidan and Carreira (2008). Moreover, in the present study, around $50 \%$ of $S$. ferrugineus seeds remained viable, as evidenced by the tetrazolium test, reiterating that these seeds show some type of dormancy.

Seeds are considered dormant when they fail to germinate under favorable conditions and also if germination takes longer than four weeks (BASKIN and BASKIN, 1998). At 20 and $25^{\circ} \mathrm{C}, \mathrm{S}$. ferrugineus seeds started germinating after 20 days, and kept germinating until 90 days (Figure 2i,l). BArbosa et al. (1985) reported dormancy in S. ferrugineus seeds, but these authors did not specify the dormancy type. Seeds of $S$. ferrugineus exhibit fully developed embryos at the dispersal time (data not shown) and have water-permeable seed coat (Kissmann et al., 2012), excluding the possibility of morphological or physical dormancy, respectively.

Gibberellin solutions are commonly used to induce germination in physiologically dormant seeds, acting both on the endosperm degradation (KARSSEN et al., 1989) as well as on the expansion of embryo cells (BEWLEY and BLACK, 1994; Roвerto et al., 2011). Gibberellic acid increased $\% \mathrm{G}$ in $S$. ferrugineus seeds from 9\% (control) to $17 \%\left(100 \mathrm{mg} \mathrm{L}^{-1} \mathrm{GA}_{3}\right.$; Figure 5). Nonetheless, the effects of $\mathrm{GA}_{3}$ on the releasing of seeds from physiological dormancy vary greatly according to the deepness of dormancy (deep, intermediate or non-deep; BASKIN and BASKIN, 2004). Therefore, our data confirmed that $S$. ferrugineus seeds are naturally dormant, as generally suggested by the literature (BARBosa et al., 1985; Zaidan and CARreira, 2008), but we were not able to demonstrate that $\mathrm{GA}_{3}$ overcome such dormancy, which would, then, be an indication of physiological dormancy. Perhaps other types of gibberellin should be tested.

Seeds of each of the three species exhibited well-distributed germination over time (Figure 2), and this behavior was also confirmed for S. camporum seeds (SIMÃo et al., 2013). The slow and non-synchronized seed germination may represent a strategy, which is suitable for unpredictable environments or seasonal climates, since this behavior prevents seeds from germinating after any particular situation (Ferreira and Borghetti, 2004). Despite differences in seed coat thicknesses of these species (S. camporum $>>$ S. ferrugineus $>$ S. pohlii; Kissmann et al., 2012), each of these species are harmoniously adapted to its respective habitats, and their fruit dispersion times seem to be adjusted to the soil water availability (KISSMANn et al., 2012). For $S$. pohlii seeds, different germination performances at distinct seed water contents (Figure 3) reinforce such dependence on soil water availability. Seeds of this species are dispersed with high water content $(50 \pm 0.5 \%)$, and exhibit the highest $\% \mathrm{G}$ under such conditions (Figure 3a). However, despite the low $\% \mathrm{G}$, the seeds are still able to germinate with $12 \%$ water content, suggesting the intermediate behavior of $S$. pohlii seeds (Ellis et al., 1990).

S. pohlii fruits are small drupes ( $5 \mathrm{~mm}$ in diameter), and this trait together with high seed water content represent limitations for wind dispersal. Thus, S. pohlii seeds are probably dispersed autochorically or zoochorically. Zoochory is crucial for seeds requiring pulp removal to germinate, as we observed for $S$. pohlii. Fruit pulps may limit germination because of germination inhibitors commonly present in the pulp (YaGIHASHI et al., 2000), or because it may offer a moist and nutritious medium for fungal infection, or even because it may represent a physical barrier for seed germination. We observed that $S$. pohlii pulp provided conditions for fungal infection, leading to $100 \%$ seed mortality. In addition, fleshy drupes of $S$. pohlii fruits are described as an important diet for birds in forest remnants (ZACA et al., 2006). As S. pohlii seeds exhibit thin seed coat and fast imbibition (KIssmann et al., 2012), as well as high $\% \mathrm{G}$ after pulp removal, as evidenced by the present study, it seems reasonable to suggest that seeds of this species is zoochorically dispersed.

Because $S$. pohlii seeds are dispersed in the rainy season, when the soil is usually flooded, the capacity of these seeds to germinate in hypoxia conditions (Figure 4) shows an important advantage of this species in flooded environments. These seed germination responses, together with the fast recovery capacity of gas exchange rates observed in S. pohlii plants after flooding periods (KIssmann et al., unpublished data), and the high specific leaf area of S. pohlii plants in riparian forests, leading to advantageous photosynthetic performances in such shaded environments (Habermann and Bressan, 2011) may explain the successful occurrence of this species in riparian forests (Teixeira and Assis, 2005).

In this descriptive study, we used important data on seed germination performances of three Styrax species obtained under laboratory conditions and complemented with germination data of these three species obtained in the field (Kissmann et al., 2012), which constituted useful information to discuss the distribution patterns of these congeneric species in Cerrado areas in Brazil. 


\section{ACKNOWLEDGEMENTS}

Camila Kissmann acknowledges the Coordenação de Aperfeiçoamento de Pessoal de Nível Superior (CAPES) for a PhD scholarship. Gustavo Habermann acknowledges the Brazilian National Council for Scientific and Technological Development $(\mathrm{CNPq})$ for a research productivity fellowship (CNPq Proc. 306119/2011-0).

\section{REFERENCES}

BARBOSA, L.M.; BARBOSA, J.M.; DOMINGOS, M.; ESTEFANO, E. Ensaios de germinação de sementes de Styrax ferrugineus Nees Mart. Revista Ecossistema, v.10, p.55-63, 1985.

BASKIN, C.C.; BASKIN, J.M. Seeds: ecology, biogeography, and evolution of dormancy and germination. San Diego: Academic Press, 1998. 666p.

BASKIN, J.M.; BASKIN, C.C. A classification system for seed dormancy. Seed Science Research, v.14, p.1-16, 2004. http://dx.doi. org/10.1079/SSR2003150

BEWLEY, J.D.; BLACK, M. Seeds: physiology of development and germination. 2nd ed. New York: Plenum Press, 1994. 445p.

BRACHO-NUNEZ, A.; KNOTHE, N.M.; COSTA, W.R.; LIBERATO, M.A.R.; KLEISS, B.; ROTTENBERGER, S.; PIEDADE, M.T.F.; KESSELMEIER, J. Root anoxia effects on physiology and emissions of volatile organic compounds (VOC) under short and long term inundation in trees from Amazon floodplains. SpringerPlus, v.1, p.1-15, 2012. http://dx.doi.org/10.1186/2193-1801-1-9

CROMARTY, A.S.; ELLIS, R.H.; ROBERTS, E.H. Design of seed storage facilities for genetic conservation. Rome: IPGRI, 1990. 100p. PMid:2200679.

DAWS, M.I.; LYDALL, E.; CHMIELARZ, P.; LEPRINCE, O.; MATTHEWS, S.; THANOS, C.A.; PRITCHARD, H.W. Developmental heat sum influences recalcitrant seed traits in Aesculus hippocastanum across Europe. New Phytologist, v.162, p.157-166, 2004. http://dx.doi.org/10.1111/j.1469-8137.2004.01012.x

ELLIS, R.H.; HONG, T.D.; ROBERTS, E.H. An intermediate category of seed storage behaviour? I. Coffee. Journal Experimental Botany, v.41, p.1167-1174, 1990. http://dx.doi.org/10.1093/jxb/41.9.1167

FENNER, M. The effects of the parent environment on seed germinability. Seed Science Research, v.1, p.75-84, 1991. http:// dx.doi.org/10.1017/S0960258500000696

FENNER, M.; THOMPSON, K. The Ecology of Seeds. Cambridge: Cambridge University Press, 2005. 260p. http://dx.doi.org/10.1017/ CBO9780511614101

FERREIRA, A.G.; BORGHETTI, F. Germinação: do básico ao aplicado. Porto Alegre: Artmed, 2004. 323p.

FURCH, K.; JUNK, W.J. Physicochemical conditions in floodplains lakes. In: JUNK, W.J. (Ed.). The Central Amazon floodplain: ecology of a pulsing system. Berlin: Springer Verlag, 1997. p.69-108. http:// dx.doi.org/10.1007/978-3-662-03416-3_4
GOLTERMAN, H.L.; CLYNO, R.S.; OHNSTAD, M.A.M. Methods for physical and chemical analysis of freshwaters. Oxford: Blackwell, 1978. 213p.

GUTTERMAN, Y. Maternal effects on seeds during development. In: FENER, M. (Ed). Seeds: The Ecology of Regeneration in Plant Communities. Wallingford: CABI Publishing, 2000. p.59-84. http:// dx.doi.org/10.1079/9780851994321.0059

HABERMANN, G.; BRESSAN, A.C.G. Root, shoot and leaf traits of the congeneric Styrax species may explain their distribution patterns in the cerrado sensu lato areas in Brazil. Functional Plant Biology, v.38, p.209-218, 2011. http://dx.doi.org/10.1071/FP10182

HABERMANN, G.; ELLSWORTH, P.F.V.; CAZOTO, J.L.; SIMAO, E.; BIERAS, A.C. Comparative gas exchange performance during the wet season of three Brazilian Styrax species under habitat conditions of cerrado vegetation types differing in soil water availability and crown density. Flora, v.206, p.351-359, 2011. http://dx.doi.org/10.1016/j. flora.2010.05.009

INTERNATIONAL SEED TEST ASSOCIATION - ISTA. International Rules for Seed Testing. Bassersdorf: ISTA, 2011.

KARSSEN, C.M.; ZAGORSKI, S.; KEPCZYNSKI, J.; GROOT, S.P.C. A key role for endogenous gibberellins in the control of seed germination. Annals of Botany, v.63, p.71-80, 1989.

KISSMANN, C.; TOZZI, H.H.; MARTINS, S.; HABERMANN, G. Germination performance of congeneric Styrax species from the Cerrado sensu lato areas and their distribution pattern in different physiognomies. Flora, v.207, p.673-681, 2012. http://dx.doi. org/10.1016/j.flora.2012.06.019

KLINK, C.A.; MACHADO, R.B. Conservation of the Brazilian Cerrado. Conservation Biology, v.19, p.707-713, 2005. http://dx.doi. org/10.1111/j.1523-1739.2005.00702.x

LABOURIAU, L.G. A germinação das sementes. Washington: OEA, 1983

LABOURIAU, L.G.; AGUDO, M. On the physiology of seed germination in Salvia hispanica L. I. Temperature effects. Anais da Academia Brasileira de Ciências, v.59, p.37-56, 1987.

PAMMENTER, N.W.; BERJAK, P. Aspects of recalcitrant seed physiology. Revista Brasileira de Fisiologia Vegetal, v.12, p.56-69, 2000.

ROBERTS, E.H. Predicting the storage life of seeds. Seed Science and Technology, v.1, p.499-514, 1973.

ROBERTO, G.G.; COAN, A.I.; HABERMANN, G. Water content and GA3-induced embryogenic cell expansion explain Euterpe edulis seed germination, rather than seed reserve mobilisation. Seed Science and Technology, v.39, p.559-571, 2011.

SIMÃO, E.; NAKAMURA, A.T.; TAKAKI, M. Germination of Styrax camporum Pohl. seeds in response to substrate types, moisture contents and the seed morphology. Anais da Academia Brasileira de Ciências, v.85, p.295-306, 2013. PMid:23460429. http://dx.doi. org/10.1590/S0001-37652013005000015

TAKAKI, M. New proposal of classification of seeds based on forms of phytochrome in stead of photoblastism. Revista Brasileira de Fisiologia Vegetal, v.13, p.103-107, 2001. http://dx.doi.org/10.1590/ S0103-31312001000100011 
TEIXEIRA, A.P.; ASSIS, M.A. Caracterização florística e fitossociológica do componente arbustivo-arbóreo de uma floresta paludosa no município de Rio Claro (SP), Brasil. Revista Brasileira de Botânica, v.28, p.467476, 2005. http://dx.doi.org/10.1590/S0100-84042005000300005

YAGIHASHI, T.; HAYASHIDA, M.; MIYAMOTO, T. Inhibition by pulp juice and enhancement by ingestion on germination of bird-dispersed Prunus seeds. Journal of Forestry Research, v.5, p.213215, 2000. http://dx.doi.org/10.1007/BF02762405
ZACA, W.; SILVA, W.R.; PEDRONI, F. Diet of the rusty-margined guan (Penelope superciliaris) in an altitudinal forest fragment of southeastern Brazil. Ornitologia Neotropical, v.17, p.373-382, 2006.

ZAIDAN, L.B.P.; CARREIRA, R.C. Seed germination in cerrado species. Brazilian Journal of Plant Physiology, v.20, p.167-181, 2008. http://dx.doi.org/10.1590/S1677-04202008000300002 